\title{
KEWENANGAN LEMBAGA PENYELESAIAN SENGKETA PERBANKAN SYARIAH
}

Kajian Putusan Mahkamah Konstitusi Nomor 93/PUU-X/2012

\section{THE AUTHORITY OF DISPUTE SETTLEMENT INSTITUTION OF SHARIA BANKING}

\author{
An Analysis of Constitutional Court's Decision Number 93/PUU-X/2012
}

\author{
Abdul Rasyid \& Tiska Andita Putri \\ Fakultas Humaniora Jurusan Business Law Universitas Bina Nusantara \\ Kampus Kijang Jl. Kemanggisan Illir III No. 45 Palmerah, Jakarta 11480 \\ Email: arasyid@binus.edu; anditatiska@gmail.com
}

Naskah diterima: 12 Oktober 2017; revisi: 19 Juli 2019; disetujui 19 Agustus 2019

http://dx.doi.org/10.29123/jy.v12i2.256

\section{ABSTRAK}

Sejak diamandemennya Undang-Undang Nomor 7 Tahun 1989 tentang Peradilan Agama dengan UndangUndang Nomor 3 Tahun 2006, kompetensi absolut peradilan agama diperluas. Pasal 55 Undang-Undang Nomor 21 Tahun 2008 tentang Perbankan Syariah memperkuat kewenangan peradilan agama dalam menyelesaikan sengketa perbankan syariah. Polemik muncul ketika Penjelasan Pasal 55 ayat (2) juga memberikan kewenangan kepada peradilan umum menyelesaikan sengketa perbankan syariah. Masalah ini lalu diajukan judicial review ke Mahkamah Konstitusi. Menurut Mahkamah Konstitusi, Penjelasan Pasal 55 ayat (2) bertentangan dengan UUD NRI RI 1945 dan tidak mempunyai kekuatan hukum mengikat. Putusan Mahkamah Konstitusi masih menimbulkan perdebatan karena hanya menghapus Penjelasan Pasal 55 ayat (2), bukan menghapus pasalnya. Permasalahan yang akan dibahas dalam tulisan ini adalah lembaga peradilan manakah yang berwenang menyelesaikan sengketa perbankan syariah pasca Putusan Mahkamah Konstitusi Nomor 93/PUU-X/2012? Penelitian ini menggunakan metodologi penelitian yuridis normatif. Penelitian ini
\end{abstract}

menyimpulkan bahwa Putusan Nomor 93/PUU-X/2012 terkait kewenangan penyelesaian sengketa perbankan syariah dianggap sudah tepat, memutuskan bahwa penyelesaian sengketa perbankan syariah harus melalui peradilan agama sesuai dengan kompetensi absolutnya. Putusan Mahkamah Konstitusi tersebut telah menghilangkan dualisme penyelesaian sengketa perbankan syariah.

Kata kunci: kompetensi, perbankan syariah, Mahkamah Konstitusi.

\section{ABSTRACT}

Since the amendment of Law Number 7 of 1989 concerning Religious Courts with Law Number 3 of 2006, the absolute competence of religious courts was, expand. Article 55 of Law Number 21 of 2008 concerning Sharia Banking strengthens the authority of the religious court in resolving sharia banking disputes. Polemic arises when the elucidation of Article 55 paragraph (2) also allowed the general court to resolve sharia banking disputes. This issue then submitted by judicial review to the Constitutional Court. According to the Constitutional 
Court, elucidation of Article 55 paragraph (2) is contrary to the 1945 Constitution of the Republic of Indonesia and has no binding legal force. The Constitutional Court Decision still raises debate because it only removes the elucidation of Article 55 paragraph (2), instead of deleting the article. The issues that will discuss in this paper are which judicial institution has the authority to settle sharia banking disputes after the Constitutional Court Decision Number 93/PUU-X/2012? This research uses a normative juridical research methodology. This research concludes that Constitutional Court Decision Number 93/PUU-X/2012 related to the authority to settle sharia banking disputes considered appropriate decides that the settlement of sharia banking disputes must go through religious courts by its absolute competence. The Constitutional Court's decision has eliminated dualism in the settlement of sharia banking disputes.

Keywords: competence, sharia banking, Constitutional Court.

\section{PENDAHULUAN}

\section{A. Latar Belakang}

Sejak diamandemennya Undang-Undang Nomor 7 Tahun 1989 dengan Undang-Undang Nomor 3 Tahun 2006 tentang Peradilan Agama, kompetensi absolut peradilan agama diperluas. Di samping diberikan kewenangan untuk memeriksa, memutus, dan menyelesaikan sengketa di tingkat pertama antara orang-orang yang beragama Islam di bidang perkawinan, waris, wasiat, hibah, wakaf, zakat, infak, dan shadaqah, peradilan agama juga berwenang untuk memeriksa, memutus, dan menyelesaikan sengketa di bidang ekonomi syariah. Hal ini diatur secara eksplisit dalam Pasal 49 huruf (i) UndangUndang Nomor 3 Tahun 2006 tentang Perubahan Pertama Atas Undang-Undang Nomor 7 Tahun 1989 tentang Peradilan Agama yang menyatakan sebagai berikut: "Pengadilan Agama bertugas dan berwenang memeriksa, memutus, dan menyelesaikan perkara di tingkat pertama antara orang-orang yang beragama Islam di bidang: (a) perkawinan; (b) waris; (c) wasiat; (d) hibah; (e) wakaf; (f) zakat; (g) infaq; (h) shadaqah; dan (i) ekonomi syariah."

Dalam penjelasannya, yang dimaksud dengan 'ekonomi syariah' adalah perbuatan atau kegiatan usaha yang dilaksanakan menurut prinsip syariah, antara lain meliputi: (a) bank syariah; (b) lembaga keuangan mikro syariah; (c) asuransi syariah; (d) reasuransi syariah; (e) reksa dana syariah; (f) obligasi syariah dan surat berharga berjangka menengah syariah; (g) sekuritas syariah; (h) pembiayaan syariah; (i) pegadaian syariah; (j) dana pensiun lembaga keuangan syariah; dan (k) bisnis syariah.

Kewenangan pengadilan agama dalam menyelesaikan sengketa perbankan diperkuat kembali dalam Pasal 55 ayat (1) Undang-Undang Nomor 21 Tahun 2008 tentang Perbankan Syariah yang menyatakan bahwa: "Penyelesaian sengketa perbankan syariah dilakukan oleh pengadilan dalam lingkungan Peradilan Agama." Namun permasalahan muncul ketika Pasal 55 ayat (2) Undang-Undang Nomor 21 Tahun 2008 juga memberi peluang kepada para pihak yang bersengketa untuk menyelesaikan perkara mereka melalui pengadilan negeri, apabila disepakati bersama dalam isi akad. Bunyi Pasal 55 ayat (2) tersebut sebagai berikut: "Dalam hal para pihak telah memperjanjikan penyelesaian sengketa selain sebagaimana dimaksud pada ayat (1), penyelesaian sengketa dilakukan sesuai dengan isi akad."

Dalam penjelasan pasal di atas, yang dimaksud dengan 'penyelesaian sengketa 
dilakukan sesuai dengan isi akad' adalah upaya sebagai berikut: a. musyawarah; b. mediasi perbankan; c. melalui Badan Arbitrase Syariah Nasional (Basyarnas) atau lembaga arbitrase lain; dan/atau d. melalui pengadilan dalam lingkungan Peradilan Umum.

Penyelesaian sengketa perbankan syariah melalui mekanisme penyelesaian sengketa alternatif di luar pengadilan seperti musyawarah, mediasi, dan arbitrase syariah merupakan langkah yang tepat dan layak untuk diapresasi. Namun permasalahan muncul ketika pengadilan negeri juga diberikan kewenangan yang sama dalam menyelesaikan sengketa perbankan syariah. Terjadi dualisme penyelesaian sengketa, ketidakpastian hukum serta tumpang tindih kewenangan dalam menyelesaikan suatu perkara yang sama oleh dua lembaga peradilan yang berbeda. Padahal, kewenangan ini jelas merupakan kewenangan pengadilan agama sebagaimana diatur dalam Pasal 49 huruf (i) Undang-Undang Nomor 3 Tahun 2006 tentang Perubahan Pertama Atas Undang-Undang Nomor 7 Tahun 1989 tentang Peradilan Agama.

Adanya dualisme dalam penyelesaian sengketa perbankan syariah, sehingga menimbulkan ketidakpastian hukum.DA, direktur $\mathrm{CV}$ BEC, mengajukan permohonan uji materi Pasal 55 ayat (2) dan (3) Undang-Undang Nomor 21 Tahun 2008 tentang Perbankan Syariah yang mengatur tentang penyelesaian sengketa terhadap Pasal 28D ayat (1) UUD NRI 1945 kepada Mahkamah Konstitusi. Menurut pemohon, Pasal 55 ayat (2) dan (3) tidak memberikan kepastian hukum sehingga bertentangan dengan Pasal 28 UUD NRI 1945.

Pada tanggal 29 Agustus 2013, Mahkamah Konstitusi membuat Putusan
Nomor 93/PUU-X/2012, mengabulkan sebagian permohonan pemohon, menyatakan bahwa penjelasan Pasal 55 ayat (2) Undang-Undang Nomor 21 Tahun 2008 tentang Perbankan Syariah bertentangan dengan UUD NRI 1945 dan tidak mempunyai kekuatan hukum mengikat.

Lebih lanjut dalam salah satu pertimbangannya, Mahkamah Konstitusi menyatakan bahwa adanya pilihan tempat penyelesaian sengketa (choice of forum) untuk menyelesaikan sengketa perbankan syariah sebagaimana tersebut dalam Penjelasan Pasal 55 ayat (2) Undang-Undang Nomor 21 Tahun 2008 akan menyebabkan adanya tumpang tindih kewenangan untuk mengadili, karena ada dua peradilan yang diberikan kewenangan untuk menyelesaikan sengketa perbankan syariah. Padahal dalam Undang-Undang Nomor 50 Tahun 2009 tentang Peradilan Agama secara tegas dinyatakan bahwa peradilan agamalah yang berwenang menyelesaikan tersebut.

Adanya putusan Mahkamah Konstitusi tersebut, maka permasalahan dualisme dalam penyelesaian sengketa perbankan syariah dianggap telah selesai. Pengadilan agama menjadi satu-satunya pengadilan yang berwenang dalam menyelesaikan sengketa perbankan syariah, akan tetapi pada kenyataannya putusan Mahkamah Konstitusi tersebut masih menimbulkan masalah. Terdapat argumentasi yang mengatakan bahwa putusan Mahkamah Konstitusi tersebut hanya menghapuskan Penjelasan Pasal 55 ayat (2) Undang-Undang Nomor 21 Tahun 2008, tapi tidak menghapus pasalnya, sehingga pasal tersebut masih tetap berlaku. Oleh karena itu, para pihak yang bersengketa tetap mempunyai kebebasan untuk memilih tempat yang mereka sepakati dalam menyelesaikan sengketanya. 


\section{B. Rumusan Masalah}

Berdasarkan latar belakang permasalahan di atas, permasalahan yang akan dibahas dalam tulisan ini adalah lembaga peradilan manakah yang berwenang menyelesaikan sengketa perbankan syariah pasca Putusan Mahkamah Konstitusi Nomor 93/PUU-X/2012?

\section{Tujuan dan Kegunaan}

Tujuan dari penelitian ini untuk mengetahui dan menganalisis lembaga peradilan manakah yang berwenang menyelesaikan sengketa perbankan syariah pasca Putusan Mahkamah Konstitusi Nomor 93/PUU-X/2012. Adapun kegunaan dan manfaat yang diperoleh dari penelitian ini adalah untuk menemukan alternatif jalan keluar dalam mengatasi permasalahan ketidakpastian hukum serta dualisme pilihan forum penyelesaian sengketa perbankan syariah yang masih tetap terjadi pasca putusan Mahkamah Konstitusi.

\section{Tinjauan Pustaka \\ 1. Definisi Perbankan Syariah}

Menurut Pasal 1 ayat (1) Undang-Undang Nomor 21 Tahun 2008 tentang Perbankan Syariah, yang dimaksud dengan perbankan syariah adalah "segala sesuatu yang menyangkut tentang bank syariah dan unit usaha syariah, mencakup kelembagaan, kegiatan usaha, serta cara dan proses dalam melaksanakan kegiatan usahanya." Sedangkan yang dimaksud dengan bank syariah menurut Pasal 1 ayat (7) adalah "bank yang menjalankan kegiatan usahanya berdasarkan prinsip syariah dan menurut jenisnya terdiri atas bank umum syariah dan bank pembiayaan rakyat syariah.”
Berdasarkan pasal di atas dapat dipahami bahwa bank syariah dalam menjalankan kegiatan usahanya harus berdasarkan kepada prinsip syariah. Prinsip syariah sebagaimana yang diatur dalam Pasal 1 ayat (12) Undang-Undang Nomor 21 Tahun 2008 adalah "prinsip hukum Islam dalam kegiatan perbankan berdasarkan fatwa yang dikeluarkan oleh lembaga yang memiliki kewenangan dalam penetapan fatwa di bidang syariah.” Lembaga yang memiliki kewenangan dalam penetapan fatwa di bidang perbankan syariah dan lembaga keuangan syariah lainnya adalah Dewan Syariah Nasional Majelis Ulama Indonesia (DSN-MUI) (Anshori, 2009: 5). Semua fatwa DSN-MUI terkait dengan lembaga perbankan syariah dan keuangan syariah harus dipatuhi oleh bank syariah.

Terkait dengan hal di atas, menurut Pasal 2 Undang-Undang Nomor 21 Tahun 2008 menyatakan bahwa: "perbankan syariah dalam melakukan kegiatan usahanya berasaskan Prinsip Syariah ..." Dalam penjelasannya yang dimaksud dengan kegiatan usaha yang berasaskan prinsip syariah, antara lain adalah kegiatan usaha yang tidak mengandung unsur:

1. riba, yaitu penambahan pendapatan secara tidak sah (batil) antara lain dalam transaksi pertukaran barang sejenis yang tidak sama kualitas, kuantitas, dan waktu penyerahan (fadhl), atau dalam transaksi pinjammeminjam yang mensyaratkan nasabah penerima fasilitas mengembalikan dana yang diterima melebihi pokok pinjaman karena berjalannya waktu (nasi'ah);

2. maisir, yaitu transaksi yang digantungkan kepada suatu keadaan yang tidak pasti dan bersifat untung-untungan;

3. gharar, yaitu transaksi yang objeknya tidak jelas, tidak dimiliki, tidak diketahui 
keberadaannya, atau tidak dapat diserahkan pada saat transaksi dilakukan, kecuali diatur lain dalam syariah;

4. haram, yaitu transaksi yang objeknya dilarang dalam syariah; atau

5. zalim, yaitu transaksi yang menimbulkan ketidakadilan bagi pihak lainnya.

Lima unsur di atas harus diperhatikan dan dipenuhi oleh lembaga perbankan syariah dalam menjalankan kegiatan usahanya. Apabila unsur tersebut tidak terpenuhi berimplikasi pada ketidakvalidan usaha yang dijalankan.

\section{Landasan Hukum Perbankan Syariah}

Pada tingkat konstitusi, legitimasi perbankan syariah di Indonesia tertuang pada Pasal 29 UUD NRI 1945, yakni bahwa Negara berdasar atas Ketuhanan Yang Maha Esa dan Negara menjamin kemerdekaan tiaptiap penduduk untuk memeluk agamanya masing-masing dan untuk beribadah menurut agamanya dan kepercayaannya itu (Anshori, 2009: 2). Sedangkan pada tingkat undangundang, eksistensi lembaga perbankan syariah mempunyai legitimasi yang kuat karena diatur secara spesifik dalam Undang-Undang Nomor 21 Tahun 2008 tentang Perbankan Syariah.

Sebelum lahirnya Undang-Undang Nomor 21 Tahun 2008, landasan hukum perbankan syariah berdasarkan kepada Undang-Undang Nomor 7 Tahun 1992 tentang Perbankan. Secara substansi, undang-undang ini merupakan peraturan perbankan nasional yang muatannya lebih banyak mengatur lembaga perbankan konvensional dibandingkan lembaga perbankan syariah. Dalam Undang-Undang Nomor 7 Tahun 1992 tidak banyak pasal yang mengatur tentang bank syariah (Rasyid, 2015a). Kata 'bank syariah' juga tidak disebutkan secara eksplisit. Undangundang ini hanya menyatakan bahwa bank boleh beroperasi berdasarkan prinsip pembagian hasil keuntungan atau prinsip bagi hasil (profit sharing) (lihat: Pasal 1 butir 12 dan Pasal 6 huruf m). Tidak disebutkannya kata 'syariah' atau 'Islam' secara eksplisit dalam undang-undang ini disebabkan masih tidak kondusifnya situasi politik pada saat itu. Pemerintah masih 'alergi' dengan penggunaan kata 'syariah' atau 'Islam' (Sjahdeini, 2000).

Pada tahun 1998, Undang-Undang Nomor 7 Tahun 1992 tentang Perbankan diamandemen dengan Undang-Undang Nomor 10 Tahun 1998. Berbeda dengan Undang-Undang Nomor 7 Tahun 1992 yang tidak mengatur secara eksplisit tentang perbankan syariah, ketentuan-ketentuan mengenai perbankan syariah dalam UndangUndang Nomor 10 Tahun 1998 lebih lengkap (exhaustive) dan sangat membantu perkembangan perbankan syariah di Indonesia. UndangUndang Nomor 10 Tahun 1998 secara tegas menggunakan kata bank syariah dan mengatur secara jelas bahwa bank, baik bank umum dan bank perkreditan rakyat, dapat beroperasi dan melakukan pembiayaan berdasarkan pada prinsip syariah (lihat: Pasal 1 butir 12; Pasal 7 huruf c; Pasal 8 ayat (1) dan (2); Pasal 11 ayat (1) dan (4a); Pasal 13; Pasal 29 ayat (3); dan Pasal 37 ayat (1) huruf c) (Rasyid, 2015a).

Meskipun telah mengatur lembaga perbankan syariah dengan cukup konprehensif, Undang-Undang Nomor 10 Tahun 1998 tentang Perbankan masih dianggap belum cukup mendukung operasional perbankan syariah di Indonesia. Di samping itu, bank syariah mempunyai karakteristik yang berbeda dengan bank konvensional, sehingga pengaturan bank 
syariah dan bank konvensional dalam satu undang-undang yang sama dipandang tidak mencukupi. Perlu adanya undang-undang khusus yang mengatur bisnis perbankan syariah secara konprehensif sebagaimana halnya Malaysia yang memiliki Islamic Banking Act, yakni undang-undang khusus yang mengatur lembaga perbankan syariah. Oleh karena itu, kehadiran undang-undang khusus perbankan syariah merupakan suatu kebutuhan yang mendesak untuk diwujudkan. Berdasarkan berbagai argumentasi di atas, pada akhirnya Undang-Undang Nomor 21 Tahun 2008 tentang Perbankan Syariah disahkan.

Selain peraturan perundang-undangan di atas, terdapat sumber hukum lain tentang perbankan syariah. Sumber hukum tersebut antara lain adalah sebagai berikut:

1. Ketentuan perundang-undangan khususnya KHUPerdata tentang Perikatan dan Undang-Undang Nomor 8 Tahun 1999 tentang Perlindungan Konsumen;

2. Peraturan-peraturan Bank Indonesia dan Otoritas Jasa Keuangan tentang perbankan syariah;

3. Fatwa-fatwa Dewan Syariah Nasional Majelis Ulama Indonesia (DSN-MUI);

4. Putusan-putusan Pengadilan Agama Indonesia dan putusan-putusan Badan Arbitrase Syariah Indonesia (Basyarnas);

5. Berbagai pandangan/doktrin dari para ilmuwan hukum mengenai aspek-aspek hukum berbagai produk keuangan syariah (Sjahdeini, 2014: 4).

Peraturan-peraturan di atas merupakan sumber hukum dan panduan bagi perbankan syariah dalam menjalankan aktivitasnya. Di samping berdasarkan kepada hukum syariah yang telah dikodifikasi dalam berbagai peraturan, perbankan syariah juga merujuk kepada peraturan-peraturan umum lainnya yang terkait dengan perbankan.

\section{Kewenangan Pengadilan Agama dalam Mengadili Sengketa}

Kata 'kewenangan' sering disebut juga dengan 'kompetensi,' yang berasal dari bahasa Belanda 'competentie.' Ketiga kata tersebut dianggap mempunyai makna yang sama (Rasyid, 1998: 25). Menurut Pasal 24 UUD NRI 1945 yang berbunyi: "kekuasaan kehakiman dilakukan oleh sebuah Mahkamah Agung dan lain-lain badan kehakiman menurut undang-undang." Pasal ini menyatakan secara eksplisit bahwa Mahkamah Agung merupakan salah satu lembaga peradilan yang menjalankan kekuasaan kehakiman dalam melakukan fungsi dan kewenangan peradilan dibantu dengan badan-badan kekuasaan peradilan yang lain (Harahap, 2001: 99). Badan-badan kekuasaan lain tersebut diatur secara jelas dalam Pasal 18 Undang-Undang Nomor 48 Tahun 2009 tentang Kekuasaan Kehakiman yang menyatakan sebagai berikut:

\begin{abstract}
"Kekuasaan kehakiman dilakukan oleh sebuah Mahkamah Agung dan badan peradilan yang berada di bawahnya dalam lingkungan peradilan umum, lingkungan peradilan agama, lingkungan peradilan militer, lingkungan peradilan tata usaha negara, dan oleh sebuah Mahkamah Konstitusi.”

Berdasarkan pasal di atas, Mahkamah Agung merupakan pengadilan negara tertinggi dari empat badan peradilan yang disebutkan di atas. Dengan kata lain, empat lingkungan peradilan yaitu peradilan umum, peradilan agama, peradilan militer, dan peradilan tata usaha negara merupakan lembaga di bawah Mahkamah Agung yang melaksanakan fungsi
\end{abstract} dan kewenangan kekuasaan kehakiman. 
Masing-masing peradilan tersebut mempunyai kompetensi yang telah diatur dalam undangundang. Dalam batas-batas kompetensi itulah masing-masing lembaga peradilan melaksanakan fungsi kewenangan mengadili. Lingkungan peradilan umum hanya kompeten memeriksa dan memutus perkara pidana umum, perdata adat, dan perdata barat. Kompetensi peradilan tata usaha negara hanya memeriksa dan memutus perkara tata usaha negara. Kompetensi peradilan militer hanya menjangkau perkara tindak pidana militer dan tindak pidana umum yang dilakukan oknum anggota TNI. Demikian pula peradilan agama, wilayah kompetensinya hanya terbatas pada bidang-bidang tertentu sebagaimana yang telah ditetapkan undang-undang (Hasan, 2010: 123).

Di samping itu, berbicara tentang kekuasaan peradilan dalam kaitannya dengan hukum acara perdata, dikenal istilah 'kekuasan relatif' dan 'kekuasaan absolut.' Kekuasaan relatif diartikan sebagai kekuasaan pengadilan yang satu jenis dan satu tingkatan, dalam perbedaannya dengan kekuasaan pengadilan yang sama jenis dan sama tingkatan lainnya. Sebagai contoh antara Pengadilan Negeri Magelang dengan Pengadilan Negeri Ponorogo, dan antara Pengadilan Agama Batanghari dan Pengadilan Agama Muaro Jambi. Kekuasaan relatif ini penting sehubungan dengan pengadilan mana orang akan mengajukan perkaranya, dan juga dengan hak eksepsi tergugat.

Kekuasaan relatif pengadilan agama diatur dalam Pasal 4 ayat (1) Undang-Undang Nomor 7 Tahun 1989 yang menyatakan bahwa: "Pengadilan agama berkedudukan di kotamadya atau di ibu kota kabupaten, dan daerah hukumnya meliputi kotamadya atau kabupaten." Namun meskipun demikian, tidak tertutup kemungkinan adanya pengecualian dalam menentukan kewenangan relatif ini sebagaimana yang dinyatakan secara eksplisit dalam penjelasan pasal tersebut. Kekuasan relatif ini mempunyai arti penting, terutama terkait dengan domisili penggugat dan tergugat dalam suatu perkara. Hal ini juga terkait erat dalam menentukan ke pengadilan agama mana para pihak akan mengajukan perkara dan hak eksepsi tergugat dalam penyelesaian suatu sengketa (Suadi, 2017: 37).

Kekuasaan absolut adalah kekuasaan yang berhubungan dengan jenis perkara atau jenis pengadilan atau tingkatan pengadilan, dalam perbedaannya dengan jenis perkara atau jenis pengadilan atau tingkatan pengadilan lainnya. Sebagai contoh pengadilan agama berkuasa atas perkawinan bagi orang yang beragama Islam, sedangkan orang selain beragama Islam menjadi kekuasaan peradilan umum (Rasyid, 1998: 2527). Oleh karena itu, pengadilan agama harus memeriksa secara teliti apakah perkara yang diajukan kepadanya termasuk dalam kekuasaan absolutnya atau tidak. Apabila perkara tersebut masuk dalam kekuasaan absolutnya, maka pengadilan agama harus menerima perkara tersebut dan tidak boleh menolaknya. Namun apabila pengadilan agama menerima perkara di luar kekuasaan absolutnya, maka pihak tergugat dapat mengajukan keberatan yang disebut dengan eksepsi absolut. Eksepsi absolut ini dapat diajukan oleh tergugat sejak tergugat menjawab pertama gugatan bahkan boleh diajukan kapan saja sampai di tingkat banding atau di tingkat kasasi (Suadi, 2017: 37).

Kewenangan masing-masing lingkungan peradilan bersifat absolut. Apa yang telah ditetapkan menjadi kewenangan dalam suatu lingkungan peradilan, maka menjadi kewenangan mutlak bagi peradilan tersebut untuk memeriksa dan memutus perkara. Kewenangan mutlak ini dinamakan dengan 'kompetensi absolut' atau 
'yurisdiksi absolut.' Oleh karena itu, setiap perkara yang tidak termasuk dalam bidang kewenangan suatu lembaga peradilan tertentu, maka peradilan tersebut tidak berwenang untuk mengadili (Harahap, 2001: 101-102).

Terkait dengan kewenangan absolut peradilan agama, awalnya diatur secara jelas dalam Pasal 49 Undang-Undang Nomor 7 Tahun 1989 tentang Peradilan Agama, di mana kewenangannya hanya terbatas pada penyelesaian sengketa atau perkara-perkara perdata perkawinan, warisan, wasiat, hibah, wakaf, sedekah berdasarkan asas personalitas keislaman.

Kewenangan absolut peradilan agama diperluas dalam menyelesaikan sengketa ekonomi syariah semenjak diamandemennya Undang-Undang Nomor 7 Tahun 1998 dengan Undang-Undang Nomor 3 Tahun 2006. UndangUndang Nomor 3 Tahun 2006 diamandemen kembali dengan Undang-Undang Nomor 50 Tahun 2009. Secara substansi tidak terdapat perubahan kompetensi absolut peradilan agama dalam undang-undang terakhir ini.

\section{Diamandemennya}

Undang-Undang

Nomor 7 Tahun 1989 tentang Peradilan Agama dengan Undang-Undang Nomor 3 Tahun 2006, kewenangan absolut peradilan agama semakin luas dan memperkokoh eksistensinya sebagai salah satu lembaga peradilan di Indonesia. Kemudian, kewenangan absolut peradilan agama dalam menyelesaikan sengketa perbankan syariah juga diperkuat dalam Undang-Undang Nomor 21 tentang Perbankan Syariah, di mana Pasal 55 ayat (1) menyatakan bahwa: "penyelesaian sengketa perbankan syariah dilakukan oleh pengadilan dalam lingkungan peradilan agama."

\section{Sengketa Perbankan Syariah}

Kata 'sengketa' dalam bahasa Inggris dikenal dengan kata 'conflict' dan 'dispute.' Kedua kata tersebut mengandung makna tentang adanya perselisihan, percekcokan atau perbedaan kepentingan antara dua pihak atau lebih. Kata 'conflict' diserap ke dalam bahasa Indonesia menjadi 'konflik,' sedangkan 'dispute' diterjemahkan ke dalam bahasa Indonesia menjadi 'sengketa' (Mujahidin, 2010: 4647). Kata 'konflik' dan 'sengketa' kadangkala digunakan secara bergantian. Namun, kedua kata tersebut pada dasarnya mempunyai perbedaan yang mendasar.

Konflik merupakan situasi di mana dua pihak atau lebih dihadapkan pada perbedaan kepentingan. Konflik tidak akan berkembang menjadi sengketa jika pihak yang merasa dirugikan menyatakan rasa ketidakpuasannya. Namun, konflik tersebut akan berkembang menjadi sengketa jika pihak yang merasa dirugikan menyatakan rasa ketidakpuasannya, baik secara langsung kepada pihak yang dianggap sebagai penyebab kerugian, maupun kepada pihak lain. Berdasarkan penjelasan di atas dapat dipahami bahwa konflik tidak dapat dihindari, namun sengketa bisa dihindari apabila konflik bisa diantisipasi. Dengan kata lain, sengketa akan terjadi ketika konflik tidak dapat dikelola dengan baik (Rasyid, 2015b: 182; Mujahidin, 2010: 47; Usman, 2013: 3).

Dalam kegiatan perbankan syariah, sengketa bisa terjadi antara bank syariah dengan nasabah. Pada umumnya, faktor utama terjadinya sengketa dikarenakan tidak terpenuhinya akad yang telah diperjanjikan antara bank syariah dengan nasabah atau tidak terpenuhinya prinsip syariah dalam akad tersebut (Mujahidin, 2010: 
41). Terkait dengan akad (kontrak) tersebut, menurut Suadi (2017: 7), terdapat beberapa bentuk akad yang dapat menimbulkan sengketa sehingga mesti diwaspadai, bentuk-bentuk akad tersebut sebagai berikut:

a. Salah satu pihak menemukan fakta bahwa syarat-syaratnya suatu akad, baik syarat subjektif maupun syarat objektif ternyata tidak terpenuhi sehingga menuntut pembatalan kontrak;

b. Akad diputus oleh salah satu pihak tanpa persetujuan pihak lain, dan terdapat perbedaan pendapat dalam menginterprestasikan isi akad oleh para pihak sehinga menimbulkan sengketa hukum;

c. Karena salah satu pihak tidak memenuhi prestasi sebagaimana yang telah diperjanjikan;

d. Terjadinya perbuatan melawan hukum (onrechtmatige daad); dan

e. Adanya risiko yang tidak diduga pada saat pembuatan akad/force majeure/ overmach.

Berdasarkan penjelasan di atas, dapat dipahami bahwa sengketa bisa terjadi antara bank syariah dengan nasabah. Pada umumya sengketa tersebut terjadi dikarenakan tidak terlaksananya perjanjian yang telah disepakati dengan baik. Oleh karena itu, pemahaman yang baik akan kontrak (akad) yang akan dilakukan penting untuk diketahui sehingga sengketa bisa dihindari.

\section{METODE}

Penelitian ini menggunakan metode penelitian yang bersifat yuridis normatif. Penelitian yuridis normatif adalah penelitian yang mengkaji berbagai peraturan perundangundangan yang berlaku atau diterapkan terhadap suatu permasalahan hukum tertentu. Penelitian hukum normatif seringkali disebut juga dengan penelitian hukum doktrinal, yaitu penelitian yang objek kajiannya adalah dokumen peraturan perundang-undangan dan bahan pustaka (Soejono \& Abdurahman, 2003: 56).

Penelitian ini pada prinsipnya berusaha menganalisis pertimbangan hukum hakim Mahkamah Konstitusi dalam Putusan Nomor 93/PUU-X/2012, dan implikasinya dalam penyelesaian sengketa perbankan syariah di Indonesia. Hal ini penting untuk dilakukan mengingat masih terdapat berbagai multitafsir yang muncul atas putusan Mahkamah Konstitusi tersebut.

Alat pengumpulan data penelitian ini melalui studi kepustakaan guna menghimpun semua informasi yang sesuai dengan topik atau masalah yang sedang diteliti. Informasi tersebut dapat diperoleh dari buku-buku ilmiah, laporan penelitian, peraturan-peraturan, sumber tertulis baik dalam bentuk cetak maupun elektronik. Bahan penelitian kepustakaan tersebut terdiri dari bahan primer dan bahan sekunder. Bahan hukum primer mencakup produk hukum yang menjadi objek kajian dan perangkat hukum yang menjadi alat analisisnya. Sedangkan bahan hukum sekunder adalah bahan hukum yang memberikan penjelasan mengenai hukum-hukum primer seperti hasil-hasil penelitian atau pendapat para pakar hukum.

\section{HASIL DAN PEMBAHASAN}

Pada tanggal 29 Agustus 2013, Mahkamah Konstitusi menjatuhkan Putusan Nomor 93/ PUU-X/2012 mengenai Judicial Review Pengujian Undang-Undang Nomor 21 Tahun 2008 tentang Perbankan Syariah terhadap UUD 
NRI 1945 yang diajukan oleh DA. Putusan ini secara umum terkait dengan Pasal 55 ayat (2) dan (3) Undang-Undang Nomor 21 Tahun 2008 tentang Perbankan Syariah yang mengatur tentang penyelesaian sengketa. Pasal 55 UndangUndang Nomor 21 Tahun 2008 tentang Perbankan Syariah berbunyi sebagai berikut:

(1) Penyelesaian sengketa perbankan syariah dilakukan oleh pengadilan dalam lingkungan peradilan agama.

(2) Dalam hal para pihak telah memperjanjikan penyelesaian sengketa selain sebagaimana dimaksud pada ayat (1), penyelesaian sengketa dilakukan sesuai dengan isi akad.

(3) Penyelesaian sengketa sebagaimana dimaksud pada ayat (2) tidak boleh bertentangan dengan prinsip syariah.

Pasal 55 ayat (2) dalam penjelasannya dijabarkan sebagai berikut: "yang dimaksud dengan 'penyelesaian sengketa dilakukan sesuai dengan isi akad' adalah upaya sebagai berikut: a. musyawarah; b. mediasi perbankan; c. melalui pengadilan dalam lingkungan peradilan umum."

Menurut pemohon, Pasal 55 ayat (2) dan (3) menimbulkan ketidakpastian hukum dan bertentangan dengan Pasal 28D ayat (1) UUD NRI 1945 yang secara tegas mengatur bahwa undangundang harus menjamin adanya kepastian hukum dan keadilan. Lebih lanjut menurutnya, terdapat kontradiksi antara Pasal 55 ayat (1), (2), dan (3). Ayat (1) secara tegas mengatur apabila terjadi perselisihan atau sengketa perbankan syariah maka harus dilaksanakan di pengadilan dalam ruang lingkup peradilan agama. Namun ayat (2)nya memberi pilihan kepada para pihak yang bersengketa untuk memilih pengadilan lain, yakni pengadilan umum, untuk menyelesaikan sengketa mereka berdasarkan isi akad yang disepakati. Hal ini bisa melahirkan multitafsir sehingga makna kepastian hukum menjadi tidak ada. Sedangkan ayat (3) tidak perlu terbit apabila tidak ada ayat (2) Pasal 55 Undang-Undang Nomor 21 Tahun 2008 tentang Perbankan Syariah.

\section{Menurut pertimbangan Mahkamah} Konstitusi, antara lain, akad (perjanjian) merupakan undang-undang bagi mereka yang membuatnya sesuai dengan ketentuan Pasal 1338 KHUPerdata, namun suatu akad tidak boleh bertentangan dengan undang-undang. Terlebih lagi undang-undang yang telah menetapkan adanya kekuasaan mutlak bagi suatu badan peradilan yang mengikat para pihak yang melakukan perjanjian. Oleh sebab itu, kejelasan dalam penyusunan perjanjian merupakan suatu keharusan. Selanjutnya, pilihan forum (choice of forum) sebagaimana diatur dalam Penjelasan Pasal 55 ayat (2) UndangUndang Nomor 21 Tahun 2008 menimbulkan persoalan konstitusionalitas yang pada akhirnya dapat memunculkan ketidakpastian hukum dan kerugian bagi nasabah dan unit usaha syariah.

Di samping adanya ketidakpastian hukum dan menimbulkan kerugian, Pasal 55 ayat (2) juga menimbulkan tumpang tindih kewenangan untuk mengadili, karena ada dua lembaga peradilan yang diberikan kewenangan untuk menyelesaikan sengketa perbankan syariah. Sedangkan Undang-Undang Peradilan Agama secara tegas menyatakan bahwa peradilan agama berwenang menyelesaikan sengketa ekonomi syariah termasuk di dalamnya perbankan syariah.

Dalam amar putusannya, Mahkamah Konstitusi mengabulkan permohonan pemohon sebagian, menyatakan bahwa Penjelasan Pasal 55 ayat (2) Undang-Undang Nomor 21 Tahun 2008 tentang Perbankan Syariah bertentangan dengan UUD NRI 1945 dan tidak mempunyai 
kekuatan hukum mengikat. Berdasarkan putusan tersebut, maka bisa diambil kesimpulan bahwa penyelesaian sengketa perbankan syariah sepenuhnya menjadi kewenangan absolut pengadilan agama. Peradilan lain, yakni peradilan umum tidak berwenang untuk menyelesaikan sengketa perbankan syariah.

Putusan Mahkamah Konstitusi tersebut masih menimbulkan polemik di kalangan para praktisi dan akademisi. Argumentasi yang dinyatakan adalah bahwa dalam putusan Mahkamah Konstitusi tersebut hanya menghapuskan Penjelasan Pasal 55 ayat (2), bukan menghapus pasal-nya, sehingga Pasal 55 ayat (2) tersebut masih tetap berlaku. Para pihak tetap diberikan kebebasan untuk menentukan forum penyelesaian sengketa sesuai dengan isi akad yang mereka sepakati (asas kebebasan berkontrak). Jadi apabila mereka sepakat di dalam kontrak menunjuk pengadilan negeri sebagai forum penyelesaian sengketa mereka, maka hal tersebut dibolehkan. Ini membuktikan bahwa penyelesaian sengketa perbankan syariah bukan merupakan kompetensi absolut peradilan agama. Ini juga sejalan dengan asas pacta sunt servanda yang disimpulkan dalam Pasal 1338 ayat (1) KUHPerdata bahwa: "semua perjanjian yang dibuat secara sah berlaku sebagai undangundang bagi mereka yang membuatnya."

Para pihak harus mematuhi dan menghormati perjanjian yang dibuatnya karena persetujuan tersebut merupakan undang-undang bagi kedua belah pihak. Hal ini diperkuat kembali oleh Pasal 1338 ayat (2) KUHPerdata yang mengatakan: "perjanjian-perjanjian tidak dapat ditarik kembali selain dengan sepakat kedua belah pihak atau karena alasan-alasan yang oleh undang-undang dinyatakan cukup untuk itu."
Berdasarkan penjelasan di atas dapat dipahami bahwa Pasal 1338 KUHPerdata menjamin kepastian hukum bagi para pihak yang sepakat dalam perjanjian untuk menyelesaikan sengketa/menundukkan diri kepada lembaga selain peradilan agama. Hal ini juga tidak kontradiktif karena para pihak diberi kebebasan untuk memilih forum yang lain namun tetap menggunakan prinsip syariah (Pramono, 2015).

Senada dengan pendapat di atas, menurut Rusyad, selaku akademisi yang juga berprofesi sebagai pengacara pada beberapa kasus perbankan syariah, dengan dikeluarkannya Putusan Mahkamah Konstitusi Nomor 93/PUU-X/2012 tidak menjadikan pengadilan agama sebagai satusatunya pengadilan yang berwenang mengatasi masalah perbankan syariah. Menurutnya, Pasal 55 Ayat (2) Undang-Undang Nomor 21 Tahun 2008 terkait penyelesaian sengketa perbankan syariah tetap esksis, yang dihapus hanya penjelasannya saja. Oleh karena itu, pilihan forum dalam penyelesaian sengketa perbankan syariah masih dapat digunakan.

Pengadilan negeri dapat dijadikan forum penyelesaian sengketa tersebut apabila disepakati oleh para pihak yang bersengketa sesuai dengan isi akad. Walaupun dalam Pasal 49 huruf (i) Undang-Undang Nomor 3 Tahun 2006 tentang Peradilan Agama menyatakan bahwa sengketa ekonomi syariah termasuk dalam kewenangan peradilan agama. Asas lex specialis derogat berlaku dalam masalah ini, di mana UndangUndang Nomor 21 Tahun 2008 menjadi peraturan yang dijadikan sebagai dasar dalam segala hal yang berkaitan dengan bank syariah termasuk dalam penyelesaian sengketanya.

Rusyad mengatakan bahwa pada praktiknya di pengadilan agama jarang ditemukan perkara 
ekonomi syariah. Pihak bank syariah lebih memilih pengadilan negeri sebagai forum penyelesaian sengketa melalui jalur litigasi (Rusyad, 2018).

Dari hasil penelusuran penulis melalui situs Mahkamah Agung menggambarkan bahwa masih terdapat lembaga perbankan syariah/unit usaha syariah yang menyelesaikan sengketanya melalui pengadilan negeri pasca putusan Mahkamah Konstitusi. Setidak-tidaknya terdapat empat bank, yaitu Bank Syariah Mandiri, Bank Mega Syariah, Bank Syariah Bukopin, dan Unit Usaha Maybank Syariah yang menyelesaikan sengketanya melalui jalur pengadilan negeri pasca putusan Mahkamah Konstitusi sampai dengan tahun 2017. umum dan kesusilaan (Pasal 1337 KUHPerdata). Berdasarkan Pasal 49 huruf (i) UndangUndang Nomor 3 Tahun 2006 tentang Peradilan Agama, jelas menyatakan bawah perkara ekonomi syariah, termasuk perbankan syariah merupakan kewenangan absolut peradilan agama. Hal ini diperkuat kembali dalam Pasal 55 ayat (1) yang menyatakan bahwa sengketa perbankan syariah diselesaikan di pengadilan dalam lingkungan peradilan agama.

Berbicara mengenai kompetensi absolut antar lingkungan peradilan, empat lingkungan peradilan yang ada, yaitu peradilan umum, peradilan agama, peradilan militer, dan peradilan tata usaha negara, sebagai pelaksana fungsi dan kewenangan kekuasaan kehakiman, telah ditentukanbatas-bataskekuasaannya olehundang-

Tabel 1. Sengketa Perbankan Syariah Melalui Pengadilan Negeri

\begin{tabular}{llll}
\multicolumn{1}{c}{ Nama Bank } & \multicolumn{1}{c}{$\begin{array}{c}\text { Nomor Putusan } \\
\text { Pengadilan Negeri }\end{array}$} & \multicolumn{1}{c}{ Pengadilan Negeri } & Tahun \\
\hline Bank Syariah Mandiri & 04/PDT.G/2013/PN.JKT.PST & Jakarta Pusat & 2013 \\
\hline Bank Mega Syariah & 75/Pdt.G/2014/PN.Krg & Karanganyar & 2014 \\
\hline Bank Syariah Bukopin & 641/Pdt.G/2016/PN.Tng & Tangerang & 2016 \\
\hline Bank Syariah Bukopin & 607/Pdt.G/2014/PN.Bdg & Bandung & 2014 \\
\hline Maybank Syariah & 10/Pdt.G/2017/PN.Dps & Denpasar & 2017 \\
\hline
\end{tabular}

Sumber: https://putusan.mahkamahagung.go.id/

Penulis sepakat dengan argumentasi di atas, bahwa berdasarkan asas kebebasan berkontrak, semua orang bebas untuk membuat perjanjian, bebas menentukan sendiri isi dan syarat-syarat perjanjian, dan bebas untuk menundukkan diri kepada hukum mana perjanjian yang mereka buat. Intinya mereka bebas membuat semua perjanjian, namun yang perlu diingat kebebasan tersebut tidaklah bersifat mutlak. Dengan kata lain, kebebasan tersebut dibatasi; tidak boleh bertentangan dengan undang-undang, ketertiban undang dalam melaksanakan fungsi kewenangan mengadili. Masing-masing lingkungan peradilan telah diatur kewenangannya dan kewenangan tersebut bersifat absolut. Dengan kata lain, peradilan hanya berwenang memeriksa dan memutus perkara berdasarkan kewenangan yang telah ditentukan, dan sebaliknya tidak berwenang menyelesaikan perkara di luar kewenangannya.

Menurut Harahap (2001: 102) tujuan dan rasio penentuan batas kewenangan setiap 
lingkungan peradilan agar terbina suatu pelaksanaan kekuasaan kehakiman yang tertib antar masing-masing lingkungan. Masingmasing berjalan sesuai dengan rel yang telah ditentukan untuk mereka lalui. Tidak saling berebut kewenangan. Di samping itu juga bisa memberi ketenteraman dan kepastian hukum bagi pihak yang berperkara. Dengan adanya pembatasan kompetensi absolut bagi masingmasing lingkungan peradilan, memberi arah yang lebih pasti bagi setiap anggota masyarakat pencari keadilan untuk mengajukan perkara. Apabila kekuasaan absolut masing-masing lingkungan peradilan tidak ditentukan, maka akan tercipta kekuasaan hakim yang kacau balau dan penegakan kepastian hukum akan hancur berantakan.

Terkait dengan permasalahan di atas, Bagir Manan mempertanyakan apakah boleh ada dua forum untuk menyelesaikan sengketa untuk suatu hukum substantif yang sama dan subjek hukum yang sama. Menurutnya, perbedaan forum diperbolehkan apabila hukum substantif dan subjek yang akan menjadi pihak atau salah satu berbeda dengan subjek pada umumnya. Apabila perbedaan forum dilakukan sedangkan hukum substantif yang akan ditegakkan sama, dan subjek yang berperkara juga sama, maka akan menimbulkan disparitas putusan yang pada akhirnya akan menimbulkan ketidakpastian hukum (Hasan, 2010: x). Kemudian, apakah Undang-Undang Nomor 21 Tahun 2008 tentang Perbankan Syariah dapat dianggap mengubah Undang-Undang Nomor 3 Tahun 2006 tentang Peradilan Agama dengan diberlakukannya asas hukum lex post erior derogat legi priori (hukum yang lebih baru menyampingkan hukum yang lebih lama) dan lex specialis derogat legi generali (hukum yang bersifat khusus menyampingkan hukum yang bersifat umum) dalam hal kompetensi peradilan agama dalam menyelesaikan sengketa ekonomi syariah.

Penting untuk diperhatikan bahwa salah satu syarat yang harus dipenuhi dalam mengaplikasikan kedua asas tersebut adalah harus dalam regim hukum yang sama. Seperti contoh, sama-sama di bidang keperdataan atau sama-sama di bidang peradilan. Asas ini tidak dapat diberlakukan pada regim hukum yang berbeda, seperti antara hukum pidana dengan hukum perdata. Dalam konteks permasalahan di atas, asas hukum lex post erior derogat legi priori tidak dapat diterapkan, karena Undang-Undang Nomor 3 Tahun 2006 adalah undang-undang tentang perubahan atas Undang-Undang Nomor 7 Tahun 1989 tentang Peradilan Agama, dan Undang-Undang Nomor 21 Tahun 2008 adalah undang-undang tentang perbankan syariah.

Kedua undang-undang tersebut berada dalam regim hukum yang berbeda. Begitu juga halnya dengan asas hukum lex specialis derogat legi generali yang tidak dapat diberlakukan atas kedua undang-undang tersebut di atas, karena di samping berbeda regim, hukum keduanya juga tidak sederajat. Keduanya bersifat spesialis. Undang-Undang Peradilan Agama adalah lex specialis dari Undang-Undang Kekuasaan Kehakiman, sedangkan Undang-Undang Perbankan Syariah adalah lex specialis dari Undang-Undang Perbankan. Dengan demikian Undang-Undang Nomor 21 Tahun 2008 tidak dapat mengesampingkan Undang-Undang Nomor 3 Tahun 2006, apalagi memindahkan wewenang peradilan agama ke peradilan lain (Hasan, 2010: xii-xiii).

Terkait dengan permasalahan di atas, menurut Muda (2016: 37-50), Putusan Mahkamah 
Konstitusi Nomor 93/PUU-X/2012 terkait kewenangan penyelesaian sengketa sejatinya, dengan berbagai penafsiran yang digunakannya, sudahlah tepat dan bijak dengan menggunakan logika formal sehingga terbentuklah keadilan legal dalam putusan tersebut, yaitu penyelesaian sengketa perbankan syariah harus melalui peradilan agama yang sesuai dengan kompetensinya; dengan menggunakan hukum Islam dalam menyelesaikan sengketa perbankan.

Menurut Yasardin, hakim agung, pasca Putusan Mahkamah Konstitusi Nomor 93/ PUU-X/2012, penyelesaian sengketa perbankan syariah merupakan kewenangan absolut pengadilan agama. Menurutnya, argumentasi yang menyatakan bahwa putusan Mahkamah Konstitusi hanya menghapus Penjelasan Pasal 55 Ayat (2) Undang-Undang Nomor 21 Tahun 2008 dan tidak menghapus pasalnya, sehingga masih memberikan peluang bagi para pihak yang bersengketa untuk menyelesaikan sengketanya melalui pengadilan umum, pada dasarnya tidak beralasan. Apabila diperhatikan secara saksama pertimbangan hakim Mahkamah Konstitusi sangat jelas, yang dipermasalahkan dalam judicial review tersebut adalah terkait dengan dualisme kewenangan antara pengadilan agama dan pengadilan umum dalam menyelesaikan sengketa perbankan syariah yang mengakibatkan ketidakpastian hukum. Putusan Mahkamah Konstitusi mempertegas kewenangan pengadilan agama dalam menyelesaikan sengketa perbankan syariah sebagaimana yang telah diatur sebelumnya dalam Undang-Undang Nomor 3 Tahun 2006 tentang Peradilan Agama (Yasardin, 2018).

Menurut Yasardin, dalam rapat pleno Pimpinan Mahkamah Agung juga telah disepakati bahwa penyelesaian sengketa perbankan syariah merupakan kewenangan pengadilan agama. Kesepakatan Pimpinanan Mahkamah Agung tersebut memperkuat Putusan Mahkamah Konstitusi Nomor 93/PUU-X/2012. Oleh karena itu, apabila ada sengketa perbankan syariah diajukan ke pengadilan umum, maka sengketa tersebut akan diputus dengan putusan Niet Ontvankelijke Verklaard (NO), yaitu gugatan tidak dapat diterima karena mengandung cacat formil. Cacat formal tersebut adalah cacat obscuur libel, ne bis in idem, atau melanggar kompetensi absolut atau relatif. Namun faktanya di lapangan masih juga terdapat beberapa kasus sengketa perbankan syariah yang masih diajukan, diproses, dan diputus oleh pengadilan umum. Menanggapi hal tersebut, Yasardin mengatakan bahwa putusan pengadilan umum tersebut pada akhirnya akan dibatalkan oleh Mahkamah Agung apabila sampai pada tahapan kasasi (Yasardin, 2018).

Menurut penulis, kesepakatan Pimpinan Mahkamah Agung dalam rapat pleno, sebagaimana yang telah dijelaskan di atas, tidaklah cukup untuk memperkuat kompetensi absolut pengadilan agama dalam menyelesaikan sengketa perbankan syariah, karena faktanya masih terdapat kasus yang diajukan ke pengadilan umum. Oleh karena itu, untuk memperkuat kompetensi absolut pengadilan agama dalam menyelesaikan sengketa perbankan syariah, dan menghilangkan perdebatan yang berkelanjutan atas Putusan Mahkamah Konstitusi Nomor 93/ PUU-X/2012, sudah semestinya Mahkamah Agung mengeluarkan peraturan, baik berupa Surat Edaran Mahkamah Agung (SEMA) atau Peraturan Mahkamah Agung (PERMA) yang menegaskan kewenangan absolut pengadilan agama dalam menyelesaikan sengketa perbankan syariah. 
SEMA atau PERMA tersebut nantinya disosialisasikan ke seluruh pengadilan, akademisi, praktisi, dan lembaga perbankan syariah untuk diketahui dan ditaati, sehingga ke depan tidak ada lagi perdebatan dan diselesaikannya sengketasengketa perbankan syariah ke pengadilan umum.

Tidak bisa dipungkiri, permasalahan di atas muncul karena masih adanya pihak-pihak, termasuk lembaga perbankan syariah sendiri, yang meragukan kemampuan pengadilan agama dalam menyelesaikan sengketa perbankan syariah. Selama ini pengadilan agama dianggap sebagai lembaga pengadilan yang hanya menyelesaikan perkara-perkara perdata terkait dengan nikah, talak, dan rujuk saja. Sehingga kemampuannya dalam menyelesaikan sengketa perbankan syariah diragukan. Jika boleh dianalogikan, keraguan atas kemampuan pengadilan agama dalam menyelesaikan sengketa perbankan syariah di atas sama halnya dengan keraguan ketika adanya keinginan untuk mendirikan bank tanpa bunga. Terdapat berbagai pihak yang meragukan dan mempertanyakan apakah mungkin bank tanpa bunga bisa beroperasi (Arifin, 2000: 18).

Seiring dengan perjalanan waktu, keraguan tersebut terbantahkan. Fakta di lapangan menunjukkan bahwa bank tanpa bunga (bank syariah) dapat eksis dan beroperasi dengan baik. Bank syariah saat ini telah berkembang dengan pesat. Berbagai negara, baik negara muslim maupun non-muslim berlomba-lomba mendirikan bank syariah. Keraguan berwujud menjadi keyakinan, bahwa bank tanpa bunga dapat beroperasi dengan baik dan menjadi lembaga keuangan alternatif. Oleh karena itu, keraguan akan kemampuan pengadilan agama dalam menyelesaikan sengketa perbankan syariah boleh saja terjadi, namun jangan sampai keraguan tersebut sampai melanggar aturan-aturan yang telah ditetapkan, sehingga menimbulkan ketidakpastian hukum. Diharapkan pengadilan agama akan membuktikan bahwa ia mampu menyelesaikan sengketa perbankan syariah dengan baik dan layak dipercaya.

Semenjak diberikan kewenangan dalam menyelesaikan sengketa ekonomi syariah pada tahun 2006, dan dengan lahirnya Putusan Mahkamah Konstitusi Nomor 93/PUU-X/2012, pengadilan agama terus berbenah diri. Namun dalam pantauan penulis, tidak ada persiapan khusus yang dilakukan oleh pengadilan umum dalam menyelesaikan sengketa perbankan syariah, baik setelah lahirnya Undang-Undang Nomor 21 Tahun 2008 tentang Perbankan Syariah maupun pasca Putusan Mahkamah Konstitusi Nomor 93/PUU-X/2012, yang masih memperdebatkan kewenangan pengadilan agama dan pengadilan umum dalam menyelesaikan sengketa perbankan syariah.

Menurut Manan (2016), berbagai usaha telah dilakukan oleh Mahkamah Agung dalam mempersiapkan pengadilan agama dalam menyelesaikan sengketa ekonomi syariah. Dari segi sarana dan prasarana, saat ini hampir semua gedung pengadilan agama dan pengadilan tinggi agama dibangun dengan fasilitas kantor yang memadai, sama halnya dengan sarana dan prasarana yang dimiliki oleh lembaga peradilan lainnya. Hampir seluruh kantor pengadilan agama dan pengadilan tinggi agama tersebut difasilitasi dengan perangkat informasi dan teknologi dalam proses penyelesaian perkara. Untuk meningkatkan kualitas para hakim dalam menyelesaikan sengketa perbankan syariah, Mahkamah Agung telah mengadakan berbagai kerjasama dalam bidang pendidikan, baik S2 dan S3 di bidang hukum bisnis/ekonomi syariah, dengan berbagai universitas negeri 
maupun swasta. Saat ini telah banyak para hakim yang mengambil kuliah S2 dan S3 di bidang ekonomi syariah. Di samping pendidikan formal, Mahkamah Agung juga melibatkan para hakim pengadilan agama dalam pendidikan nonformal. Sebagai contoh dengan mengikuti short training tentang keuangan syariah di Markfiled Institute of Higher Education (MIHE) Leicester Inggris, dan mengikuti diklat ekonomi syariah di Sekolah Tinggi Peradilan, Universitas Al-Imam Muhammad Ibnu Saud, Riyadh, Saudi Arabia pada tahun 2015 .

Dari segi peraturan perundang-undangan, Mahkamah Agung juga telah menyusun Kompilasi Hukum Ekonomi Syariah (KHES) dan mengeluarkan PERMA Nomor 2 Tahun 2008 tentang Kompilasi Hukum Ekonomi Syariah, yang mengharuskan para hakim di pengadilan agama merujuk kepada KHES dalam menyelesaikan sengketa ekonomi syariah. Dengan kata lain, KHES merupakan sumber materil para hakim di pengadilan agama dalam menyelesaikan sengketa perbankan dan ekonomi syariah.

Mahkamah Agung juga mengeluarkan PERMA Nomor 5 Tahun 2016 tentang Sertifikasi Hakim Ekonomi Syariah. Berdasarkan PERMA ini, hanya hakim yang telah tersertifikasi saja yang boleh menyelesaikan sengketa ekonomi syariah, termasuk perbankan syariah. Para hakim di pengadilan agama tersebut telah dinyatakan lulus seleksi administrasi, kompetensi, integritas, dan pelatihan menjadi hakim ekonomi syariah. Tujuan dilakukannya sertifikasi hakim ekonomi syariah untuk meningkatkan efektivitas penanganan perkara-perkara ekonomi syariah di pengadilan agama/mahkamah syariah, sebagai bagian dari upaya penegakan hukum ekonomi syariah yang memenuhi rasa keadilan (lihat: Pasal 3 PERMA Nomor 5).
Kegiatan Sertifikasi Hakim Ekonomi Syariah diadakan oleh Mahkamah Agung bekerja sama dengan berbagai lembaga terkait seperti MUI, DSN, Basyarnas, OJK, dan DPS. Berdasarkan penjelasan di atas dapat dipahami bahwa hakim yang akan menyelesaikan sengketa ekonomi syariah adalah hakim khusus yang mempunyai pemahaman yang baik tentang ekonomi syariah. Oleh karena itu, kekhawatiran akan kemampuan para hakim pengadilan agama dalam menyelesaikan sengketa perbankan syariah mestinya tidak harus diperdebatkan lagi.

Terkait dengan pembahasan di atas, pada tanggal 22 Desember 2016, Mahkamah Agung kembali menerbitkan PERMA Nomor 14 Tahun 2016 tentang Tata Cara Penyelesaian Sengketa Ekonomi Syariah. PERMA ini lalu diumumkan dan diundangkan dalam Lembaran Negara Nomor 5029 pada tanggal 29 Desember 2016. Poin terpenting yang diatur dalam PERMA Nomor 14 Tahun 2016 tentang Tata Cara Penyelesaian Sengketa Ekonomi Syariah ini adalah terkait dengan tata cara pemeriksaan perkara. PERMA ini mengatur secara eksplisit bahwa perkara ekonomi syariah dapat diajukan dengan dua mekanisme, yakni melalui gugatan sederhana (small claim court) dan gugatan dengan acara biasa (lihat: Pasal 2 PERMA Nomor 14 Tahun 2016).

\section{Pengaturan ini pada prinsipnya} membedakan tata cara pemeriksaan perkara dengan nilai objek materil yang nilainya kecil dan besar, dengan tujuan supaya perkara ekonomi syariah dapat diselesaikan dengan cepat, sederhana, dan biaya murah. Di samping itu, pembagian dua mekanisme tersebut dilakukan karena hukum acara perdata yang ada, seperti Reglemen Indonesia yang diperbarui Herzien Inlandsch Reglement, Rechtreglement voor de 
Buitengewesten $(\mathrm{RBg})$ tidak mengatur secara jelas tentang itu.

Terkait dengan tata cara pemeriksaan perkara dengan gugatan sederhana, Pasal 3 ayat (2) PERMA Nomor 14 Tahun 2016 menjelaskan bahwa yang dimaksud dengan pemeriksaan perkara dengan acara/gugatan sederhana adalah "pemeriksaan terhadap perkara ekonomi syariah yang nilainya paling banyak Rp200.000.000,(dua ratus juta rupiah)." Selanjutnya, Pasal 3 ayat (3) menyatakan bahwa pemeriksaan perkara/ gugatan sederhana tersebut merujuk kepada PERMA Nomor 2 Tahun 2015 tentang Tata Cara Penyelesaian Gugatan Sederhana kecuali hal-hal yang diatur secara khusus dalam PERMA ini.

Berdasarkan pasal di atas, dapat dipahami bahwa perkara ekonomi syariah dengan nilai maksimal dua ratus juta rupiah dapat diselesaikan dengan tata cara sederhana. Pemeriksaan dengan acara sederhana harus selesai paling lama dua puluh lima hari sejak hari sidang pertama (PERMA Nomor 2 Tahun 2015). Adapun perkara ekonomi syariah yang nilainya di atas dua ratus juta rupiah, diselesaikan dengan acara biasa yang dilakukan dengan berpedoman pada hukum acara yang berlaku (lihat: Pasal 7 ayat (1)).

Berdasarkan penjelasan di atas dapat dipahami bahwa penyelesaian sengketa perbankan syariah merupakan kewenangan absolut peradilan agama. Tidak tepat apabila dikatakan memberikan kewenangan absolut kepada kepada dua pengadilan dalam menyelesaikan sengketa perbankan syariah tidak menimbulkan ketidakpastian hukum. Namun sebaliknya, penyelesaian sengketa akan menjadi semakin tidak jelas. Para pihak akan memilih lembaga peradilan yang mereka suka. Pihak penggugat bisa mengajukan ke pengadilan umum, atau pengadilan tata usaha negara dan pihak lawan mengajukan ke pengadilan agama. Lalu masingmasing pengadilan memberikan putusan yang berbeda-beda sehingga menjadi kacau balau dan tidak ada lagi penegakan dan kepastian hukum.

Pengadilan agama juga harus berbenah mempersiapkan diri dalam menyelesaikan sengketa perbankan dan ekonomi syariah sebagai kewenangan baru yang dimilikinya. Berbeda dengan pengadilan umum yang tidak melakukan persiapan khusus dalam menyelesaikan sengketa perbankan, sehingga apabila tetap dipaksakan untuk menangani sengketa perbankan syariah, dikhawatirkan putusannya tidak sesuai dengan prinsip syariah. Di pengadilan agama, kualitas hakim dan panitera dalam ilmu ekonomi syariah terus ditingkatkan. Berbagai sarana dan prasarana dengan fasilitas yang baik juga telah dimiliki, sehingga persepsi inferior terhadap kapabilitas hakim dalam menyelesaikan sengketa perbankan syariah tidak mesti ada lagi. Usaha yang harus dilakukan terus-menerus oleh pengadilan agama adalah membangun trust (kepercayaan) masyarakat/pelaku ekonomi syariah terhadap pengadilan agama, agar mereka yakin bahwa pengadilan agama mampu dan siap untuk menyelesaikan sengketa ekonomi syariah yang diajukan kepadanya.

\section{KESIMPULAN}

Putusan Mahkamah Konstitusi pada hakikatnya diharapkan dapat memberikan kepastian hukum. Hakim Mahkamah Konstitusi haruslah hati-hati dan bijak dalam mengeluarkan suatu putusan. Putusan Mahkamah Konstitusi Nomor 93/PUU-X/2012 terkait kewenangan penyelesaian sengketa perbankan syariah dianggap sudah tepat, memutuskan bahwa 
penyelesaian sengketa perbankan syariah harus melalui peradilan agama sesuai dengan kompetensi absolutnya, sebagaimana yang diatur dalam Undang-Undang Nomor 3 Tahun 2006 tentang Peradilan Agama. Dengan kata lain, putusan Mahkamah Konstitusi tersebut telah menghilangkan dualisme penyelesaian sengketa perbankan syariah, dan memperkuat eksistensi peradilan agama sebagai satu-satunya lembaga peradilan yang berwenang menyelesaikan sengketa perbankan syariah. Namun di sisi lain, putusan Mahkamah Konstitusi menimbulkan penafsiran baru. Putusan Mahkamah Konstitusi hanya menghapus Penjelasan Pasal 55 ayat (2) Undang-Undang Nomor 21 tentang Perbankan Syariah, tapi tidak menghapus pasalnya. Sehingga membuka peluang bagi para pihak yang bersengketa untuk tetap menyelesaikan sengketanya di pengadilan negeri.

Fakta di lapangan menunjukkan bahwa masih ada beberapa lembaga perbankan syariah yang menyelesaikan sengketanya di pengadilan negeri pasca putusan Mahkamah Konstitusi. Hal ini memperkuat pendapat bahwa peradilan agama bukanlah satu-satunya badan peradilan yang berwenang menyelesaikan sengketa perbankan syariah.

Dualisme dan ketidakpastian hukum dalam penyelesaian sengketa perbankan syariah masih tetap terjadi. Di samping itu, kesepakatan Pimpinan Mahkamah Agung dalam rapat pleno yang menegaskan Putusan Mahkamah Konstitusi Nomor 93/PUU-X/2012, bahwa sengketa perbankan syariah menjadi kewenangan pengadilan agama juga dianggap tidaklah cukup. Oleh karena itu, peran Mahkamah Agung sebagai lembaga tertinggi peradilan yang membawahi peradilan agama dan peradilan negeri sangat diperlukan.
Mahkamah Agung mesti mempertegas dari dua pengadilan tersebut, mana yang lebih berwenang dalam menyelesaikan sengketa perbankan syariah. Kesepakatan Pimpinan Mahkamah Agung dalam rapat pleno tersebut bisa dipertegas kembali dalam bentuk Surat Edaran Mahkamah Agung (SEMA) atau Peraturan Mahkamah Agung (PERMA). SEMA atau PERMA tersebut nantinya disosialisasikan ke seluruh pengadilan, akademisi, praktisi, dan lembaga perbankan syariah untuk diketahui dan ditaati. Diharapkan ke depan tidak ada lagi perdebatan dualisme penyelesaian sengketa perbankan syariah, hingga bisa memberikan kepastian hukum.

\section{DAFTAR ACUAN}

Anshori, A.G. (2009). Hukum perbankan syariah (UU No. 21 Tahun 2008). Bandung: PT Refika Aditama.

Arifin, Z. (2000). Memahami bank syariah: Lingkup, peluang, tantangan \& prospek. Jakarta: AlvaBet.

Harahap, Y.M. (2001). Kedudukan kewenangan \& acara peradilan agama UU No. 7 Tahun 1989. Jakarta: Sinar Grafika.

Hasan, H.H. (2010). Kompetensi peradilan agama dalam penyelesaian perkara ekonomi syariah. Jakarta: Gramata Publishing.

Manan, A. (2016). Kebijakan MA-RI menyambut ekonomi syariah sebagai kompetensi peradilan agama. Kuliah Umum tentang Penyelesaian Sengketa Ekonomi Syariah di Indonesia: Peluang dan Tantangan. Diadakan oleh Jurusan Business Law, Binus University. 
Muda, I. (2016, April). Penafsiran hukum yang membentuk keadilan legal dalam penyelesaian sengketa perbankan syariah: Kajian Putusan Mahkamah Konstitusi Nomor 93/PUU-X/2012. Jurnal Yudisial, 9(1), 37-50.

Mujahidin, A. (2010). Kewenangan \& prosedur penyelesaian sengketa ekonomi syariah di Indonesia. Bogor: Ghalia Indonesia.

Pramono, N. (2015). Konsekuensi hukum akad yang mencantumkan pilihan hukum penyelesaian sengketa syariah pasca putusan MK No. 93/2012 dikaitkan dengan Pasal 1338 Kuhpdt. Paper dipresentasikan pada Seminar Penyelesaian Sengketa Perbankan Syariah dengan Nasabah Pasca Putusan MK Terkait Pasal 55 Ayat 2 UU Perbankan Syariah. Jakarta: Hotel Sahid.

Rasyid, A. (2015b). Penyelesaian sengketa bisnis di luar pengadilan. Dalam Shidarta, Rasyid, A., \& Sofian, A. (Eds). Aspek hukum ekonomi \& bisnis. Jakarta: Binus Media \& Publishing.

(2015a). Hukum perbankan syariah di Indonesia. Diakses dari http://business-law. binus.ac.id/2015/06/02/hukum-perbankansyariah-di-indonesia/

Rasyid, R.A. (1998). Hukum acara peradilan agama. Jakarta: PT RajaGrafindo Persada.

Rusyad, A. (2018). Wawancara pada tanggal 27 Juni 2018 di Universitas Bina Nusatara.

Sjahdeini, S.R. (2000, Agustus-September). Perbankan syariah suatu alternatif kebutuhan pembiayaan masyarakat. Jurnal Hukum Bisnis, $20,8-15$.

. (2014). Perbankan syariah: Produkproduk \& aspek-aspek hukumnya. Jakarta: Kencana.

Soejono \& Abdurahman, H. (2003). Metode penelitian hukum. Jakarta: Rineka Cipta.
Suadi, A. (2017). Penyelesaian sengketa ekonomi syariah: Teori \& praktik. Jakarta: Kencana.

Usman, R. (2013). Pilihan Penyelesaian Sengketa di luar pengadilan. Bandung: PT Citra Aditya Bakti.

Yasardin, (2018). Wawancara pada tanggal 15 November 2018 di Mahkamah Agung Republik Indonesia. 